\title{
Zoned Cr-spinel and ferritchromite alteration in forearc mantle serpentinites of the Rio San Juan Complex, Dominican Republic
}

\author{
B. M. SAUMUR ${ }^{1,2, *}$ AND K. HATTORI ${ }^{1}$
}

1 Department of Earth Sciences, University of Ottawa, 140 Louis Pasteur, Ottawa, Ontario K1N 6N5, Canada

2 School of Geosciences, Monash University, Building 28, Clayton, Victoria 3800, Australia

[Received 25 October 2011; Accepted 16 December 2012; Associate Editor: Chris Hayward]

\section{ABSTRACT}

Ferritchromite is rarely reported in forearc mantle peridotites. This contribution describes ferritchromite alteration and zoned Cr-spinel in serpentinites from the Rio San Juan Complex in the Dominican Republic. These rocks originated from the forearc mantle and protruded along lithosphere-scale faults in the mid Eocene. The cores of the $\mathrm{Cr}$-spinel grains have $\mathrm{Cr} \#$ ratios [i.e. atomic $\mathrm{Cr} /(\mathrm{Cr}+\mathrm{Al})$ ] between 0.48 and 0.66 ; such values are relatively high and are considered to represent primary compositions. Relatively high $\mathrm{Zn}$ contents in the grain cores $(0.46-0.95 \mathrm{wt} . \% \mathrm{ZnO})$ are also thought to be primary; they reflect exceptionally cool conditions in the northern Caribbean forearc mantle. A progressive change in the zoning of Cr-spinel is recorded in the samples. Weakly zoned grains of $\mathrm{Cr}$-spinel have rims with lower $M g \#$ ratios [i.e. atomic $\left.\mathrm{Mg} /\left(\mathrm{Mg}+\mathrm{Fe}^{2+}\right)\right]$ and slightly higher $\mathrm{Cr} \#$ ratios than the cores. More strongly zoned grains of $\mathrm{Cr}$-spinel, in addition to low $\mathrm{Mg \#}$ and high $\mathrm{Cr} \#$ in their rims, have a marked increase in $\mathrm{Fe}^{3+} \#$ [i.e. $\mathrm{Fe}^{3+} /\left(\mathrm{Fe}^{3+}+\mathrm{Al}+\mathrm{Cr}\right)$ ] of up to 0.35 in their rims and are partially coated by $\mathrm{Mg}$-rich chlorite. All grains show core-to-rim decreases in their $\mathrm{Zn}$ content and increases in Ti, $\mathrm{Mn}$ and $\mathrm{V}$. The association with Mg-rich chlorite and the compositional zoning are reminiscent of those reported for ferritchromite. Ferritchromite (with $\mathrm{Fe}^{3+} \#>0.5$ ) is common in ultramafic rocks in amphibolite-grade terranes; however, the serpentinite samples described herein show little evidence of high-grade metamorphism. The lowtemperature serpentine-group mineral lizardite is dominant and high-temperature antigorite is either very rare or absent; other high-temperature minerals, such as talc, tremolite and cummingtonite, are trace constituents. The observed zoning in the Cr-spinel is thought to represent 'immature' ferritchromite, probably formed in response to a short-lived thermal event. This event appears to have been on too short a timescale to produce either proper ferritchromite or significant quantities of high-temperature minerals. It may be related to the emplacement of the nearby Rio Boba Intrusion, or the upward protrusion of the serpentinites along the lithosphere-scale Septentrional fault zone from the base of the mantle wedge through its hotter interior. We suggest that such alteration is rare in forearc serpentinites because they are not commonly heated during exhumation along the plane of subduction. This work demonstrates that Cr-spinel compositions can be modified by relatively low-grade metamorphism.

KEYwoRDs: alteration, serpentinization, zinc, ferritchromite, forearc mantle, Septentrional Fault, exhumation, Hispaniola, northern Caribbean margin.

\section{Introduction}

Chromium-Spinel (chromite) is used as a petrological indicator in a wide variety of mafic and

* E-mail: benoit.saumur@monash.edu DOI: $10.1180 /$ minmag.2013.077.1.11 ultramafic rocks (e.g. Irvine, 1967; Dick and Bullen, 1984; Barnes and Roeder, 2001), and is 


\section{B. M. SAUMUR AND K. HATTORI}

especially useful in evaluating the tectonic provenance of serpentinites (e.g. Hattori and Guillot, 2007) because it is commonly the only primary mineral preserved in hydrated peridotites. However, Cr-spinel compositions can be modified during serpentinization and metamorphism. A notable common alteration of $\mathrm{Cr}$-spinel involves an increase in $\mathrm{Fe}^{3+}$ and $\mathrm{Fe}^{2+}$ contents at the expense of $\mathrm{Al}^{3+}$ and $\mathrm{Mg}^{2+}$, respectively, without major change in $\mathrm{Cr}_{2} \mathrm{O}_{3}$ (e.g. Barnes and Roeder, 2001). The resulting high $\mathrm{Fe}$ and $\mathrm{Cr}$ spinel, informally known in the literature as 'ferritchromite' or 'ferritchromit' (Spangenberg, 1943, and cited in, among others, Evans and Frost, 1975 and González-Jiminez et al., 2009), has been extensively studied and reported from a variety of locations (e.g. Beeson and Jackson, 1969; Ulmer, 1974; Onyeagocha, 1974; Bliss and MacLean, 1975; Pinsent and Hirst, 1977; Barnes, 2000;
Standish et al., 2002; Säntti et al., 2006; Merlini et al., 2009; González-Jiminez et al., 2009).

These reported occurrences of ferritchromite are hosted by metamorphosed serpentinites within a variety of tectonic settings. However, the occurrence of ferritchromite in forearc mantle peridotites is very rare and, to our knowledge, has only been reported from hydrated forearc peridotites of the Omi serpentinite mélange in the Hida Mountains of northern Japan (Tsujimori et al., 2004).

This manuscript reports a new occurrence of ferritchromite and zoned Cr-spinel in forearc mantle serpentinites exposed along a major deformation zone in the northern Dominican Republic. These samples record progressive changes in Cr-spinel compositions, which represent the onset of alteration to ferritchromite. Furthermore, these data suggest that there is

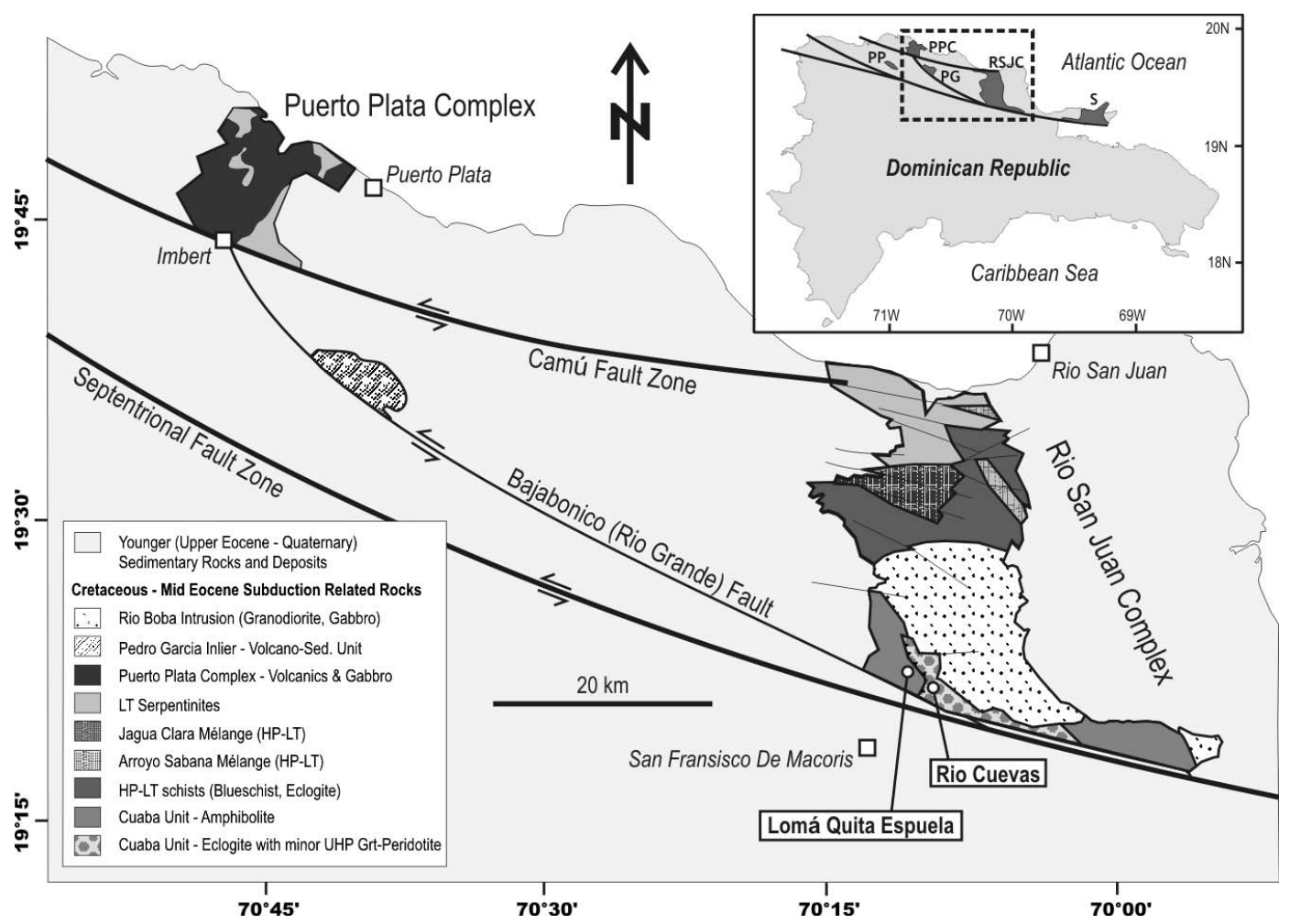

Fig. 1. Map of the investigated area, modified from Draper and Nagle (1991) and Saumur et al. (2010). Cuaba serpentinites are found in the Rio Cuevas and Lomá Quita Espuela areas located near the Septentrional Fault Zone (SFZ) northeast of San Fransisco de Macoris. The location of the study area is shown in the inset. Inliers containing subduction related rocks are also shown: S, Samaná; PP, Palma Picada; PG, Pedro Garcia; PPC, Puerto Plata Complex; RSJC, Rio San Juan Complex. 
significant mobility of major and trace elements in Cr-spinel even at low degrees of metamorphism. We also speculate on potential reasons for which ferritchromite alteration is uncommon in forearc mantle serpentinites.

\section{Geological setting}

Surface exposures in the northern Dominican Republic consist largely of Upper Eocene to Pliocene sedimentary rocks and Quaternary deposits (Lewis et al., 1990). Older rocks crop out in five inliers which expose subductionrelated units of the Rio San Juan complex (RSJC), the Puerto Plata complex, the Pedro Garcia inlier, the Palma Picada inlier and the Samaná Peninsula complex (Fig. 1). These rocks were formed during the subduction of ProtoCaribbean lithosphere (the southern portion of the North American plate) under the northern margin of the Caribbean plate between the late Cretaceous and mid Eocene (e.g. Pindell et al., 2012). Subduction ceased in response to the oblique collision of the Bahamas Platform (North American plate), and this collision resulted in the development of sinistral transform faults along the northern Caribbean margin. The
Septentrional and Camú fault zones are two such sinistral transform faults in the northern Dominican Republic (e.g. Mann and Gordon, 1996).

Serpentinites are exposed in the Puerto Plata complex and the RSJC. The Puerto Plata Complex is interpreted to be a deformed ophiolitic complex (Pindell and Draper, 1991) and contains brecciated and sheared serpentinites, tectonized harzburgite, gabbro and volcanic rocks. The RSJC is divided into three components: the northern, central and southern parts. The northern part of the RSJC (also known as the Gaspar Hernandez Serpentinites) is similar to the Puerto Plata complex, and consists of brecciated and massive serpentinites of low metamorphic grade. The central and southern parts of the RSJC expose a fossil subduction channel in which subducted oceanic lithosphere and mantle wedge peridotites physically mingled [according to the interpretations of Gorczyk et al. (2007) and Krebs et al. (2008)]. The central part consists of retrogressed blueschists and eclogites and two serpentinite mélanges (the Jagua Clara and Arroyo Sabana mélanges) which contain metre-scale blocks of blueschist, eclogite and metamorphosed felsic rock aligned with a sub-vertical foliation.

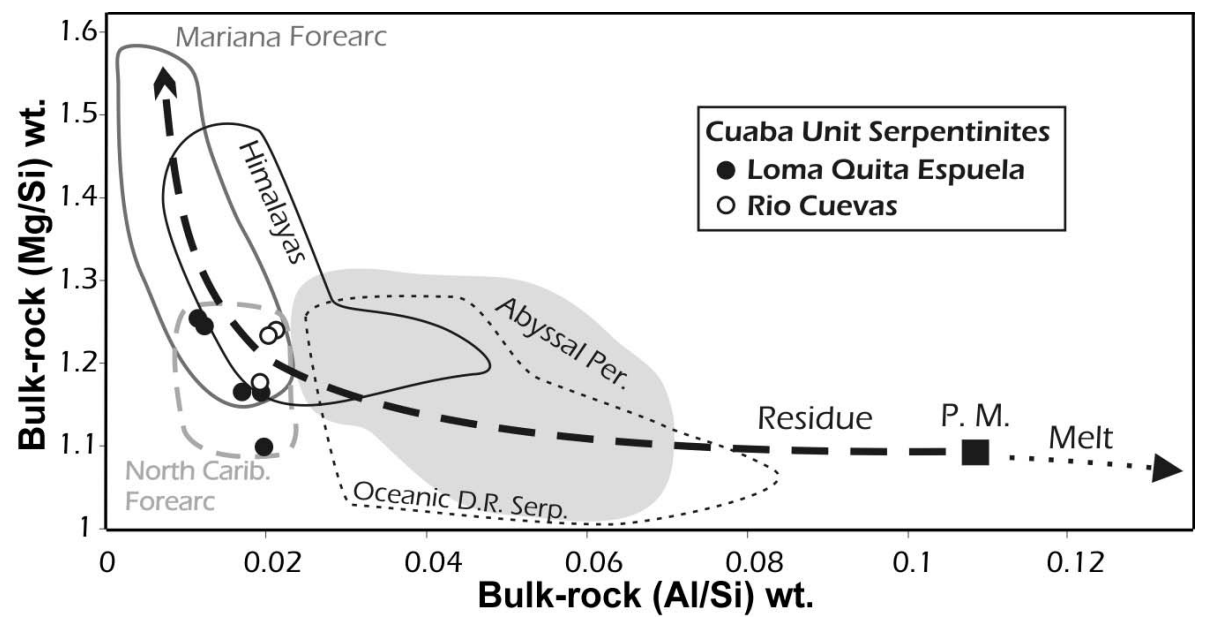

FIG. 2. The $\mathrm{Mg} / \mathrm{Si}$ vs. $\mathrm{Al} / \mathrm{Si}$ bulk rock weight ratios of serpentinites in the Cuaba Unit, modified from Saumur et al. (2010). The compositional variations expected during progressive partial melting are shown by the arrows, and primitive mantle values (P.M.) are taken from McDonough and Sun (1995). Bulk-rock compositions of Cuaba Unit serpentinites reported by Saumur et al. (2010) are consistent with a forearc mantle origin. Data sources are as follows: Mariana forearc serpentinites (Ishii et al., 1992; Parkinson and Pearce, 1998); serpentinites from Talnakh, Himalayas (Guillot et al., 2001); forearc serpentinites from the northern Caribbean margin (Bowin et al., 1966; Hattori and Guillot, 2007; Saumur et al., 2010); and abyssal peridotite (Abyssal Per., Niu, 2004; Oceanic DR Serp,

Saumur et al., 2010). 
Retrogressed eclogitic rocks originating from oceanic protoliths (Hattori et al., 2010a) are the dominant rocks in the southernmost unit of the RSJC and are described herein as the Cuaba Unit [these are described as the Cuaba Amphibolite in some earlier publications (e.g. Draper and Nagle, 1991)]. Small amounts of ultra high pressure (UHP) garnet peridotite have been reported along the Rio Cuevas stream (Fig. 1); the origin of these UHP rocks is currently a matter of debate (e.g. Abbott and Draper, 2010; Hattori et al., 2010a,b; Gazel et al., 2011; De Hoog, 2012; Gazel et al., 2012).

Serpentinites represent only minor components of the eclogitic Cuaba Unit. They form lenticular bodies within the unit (Hattori et al., 2010a; Saumur et al., 2010) which crop out $\sim 10 \mathrm{~km}$ northeast of San Fransisco de Macoris (Fig. 1). In the Lomá Quita Espuela area, the serpentinites form $100 \mathrm{~m}$ scale exposures along gravel roads. They are generally massive and locally exhibit a steeply dipping foliation of moderate intensity. The serpentinites are also abundant as large angular boulders, up to $\sim 1 \mathrm{~m}$ in size, along the Rio Cuevas. Although they were not located in situ, the large size, shape and the abundance of these boulders in a narrow $(5-10 \mathrm{~m})$ and shallow $(<1 \mathrm{~m})$ stream suggest a proximal source.

An analysis of whole-rock geochemistry and primary Cr-spinel compositions by Saumur et al. (2010) showed that two types of serpentinite occur in the northern Dominican Republic. The first type is present in large volumes within the subduction complex and occurs in the Puerto Plata Complex, Gaspar Hernandez Serpentinites, Jagua Clara Mélange and Arroyo Sabana Mélange. These serpentinites have high $\mathrm{Al}$ and low $\mathrm{Mg}$ bulk-rock compositions and contain relatively chromium-poor $\mathrm{Cr}$-spinel; these characteristics are consistent with an abyssal peridotite origin. The second type of serpentinite is interpreted as originating from forearc mantle peridotites. It occurs along the major Septentrional and Camú strike-slip fault zones, and has high $\mathrm{Mg}$ and low Al bulk-rock compositions (Fig. 2) and contains chromiumrich Cr-spinel (Fig. 3). On the basis of the distribution of forearc serpentinites and the observed deformation fabrics within the serpentinites and host rocks, the forearc serpentinites are considered to have protruded from the base of a mantle wedge to shallow crustal levels along fault zones during post-Eocene transpression (Saumur et al., 2010). These relatively buoyant serpenti-
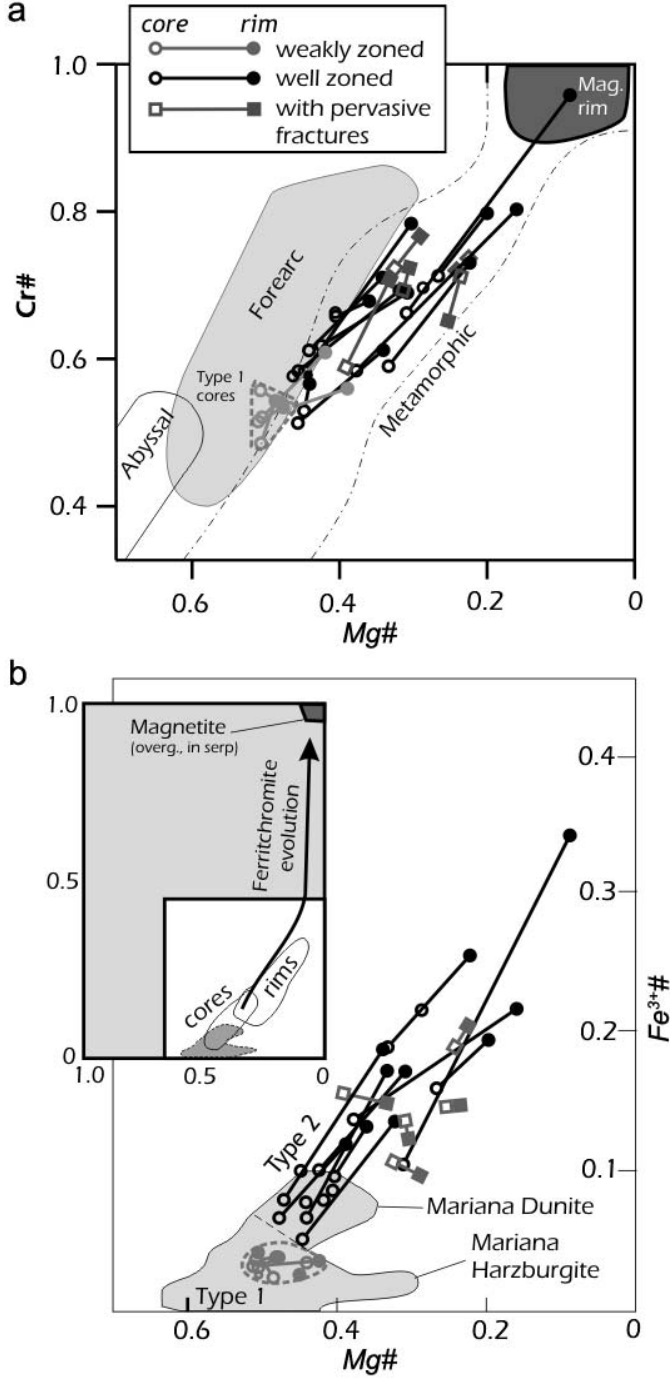

FIG. 3. Composition of cores and rims of zoned Cr-spinels; (a) Cr\# vs. Mg\# and (b) $\mathrm{Fe}^{3+} \#$ vs. Mg\#. Open circles and squares represent the cores of grains and filled symbols represent the rims. One core-rim pair represents one grain. The legend remains the same for subsequent figures. The forearc field is defined by spinel in peridotites from the Mariana Forearc (Ishii et al., 1992) and the abyssal peridotite field is after Dick and Bullen (1984). The field of metamorphic Cr-spinels was redrawn from Säntti et al. (2006) after Evans and Frost (1975).

nites probably contributed to the exhumation of HP and UHP rocks in the subduction channel (Gorczyk et al., 2007; Hattori et al., 2010a). 
The RSJC includes the Rio Baba Intrusion (Fig. 1), which has not been the focus of extensive study. It consists of granodiorite and gabbro and is thought to have intruded the Cuaba Unit (Draper and Nagle, 1991). The timing of its emplacement relative to regional faulting is not known, but intrusion contacts appear to be at least partly faultcontrolled, suggesting that emplacement was relatively late. No obvious contact aureole has been observed, but its emplacement may, never-
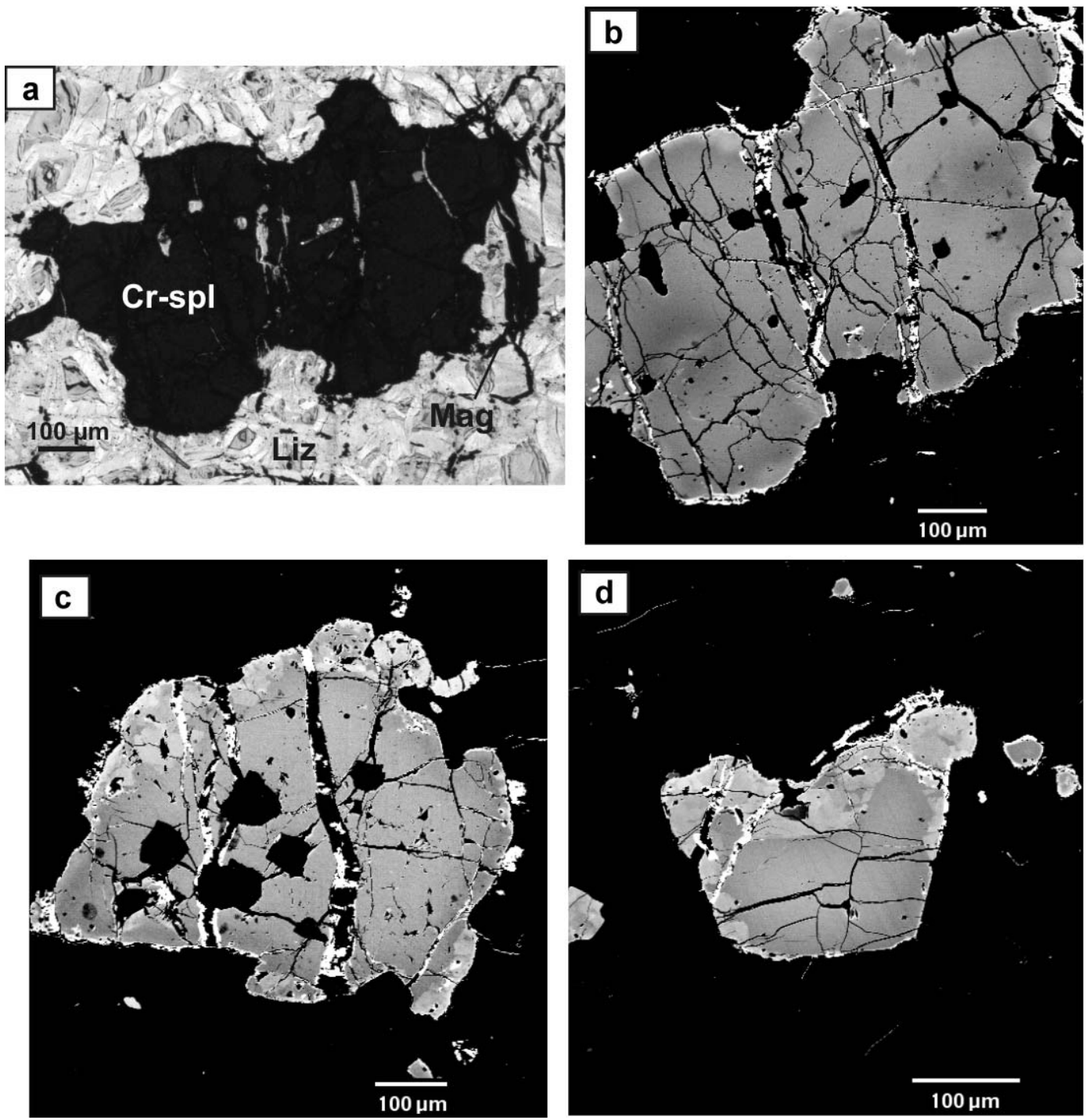

Fig. 4. Examples of weakly-zoned Cr-spinels. (a) Transmitted-light image of Cr-spinel, with pseudomorphic lizardite (Liz) forming the bulk of the serpentinite groundmass and minor magnetite (Mag) located at grain edges. (b) Backscattered-electron image of the grain shown in Fig. 3a. Darker zones within the Cr-spinel grain have slightly higher $\mathrm{Cr}$. Note the bright magnetite in the cracks. (c) Backscattered-electron image of $\mathrm{Cr}$-spinel, generally not zoned except for patchy reflective zones near rims (upper part and lower right side of grain) which are due to lower $M g \#$. Highly reflective magnetite overgrowths occur in fractures within grains. The black material is lizardite. The embayed nature of the grain suggests a primary morphology. $(d)$ Backscattered-electron image of weakly zoned $\mathrm{Cr}$-spinel with slightly higher $\mathrm{Fe}$ in the rim. Magnetite fills cracks and surrounds the upper right corner of the spinel. 


\section{B. M. SAUMUR AND K. HATTORI}

theless, have caused slight metamorphism of neighbouring Cuaba Unit.

This contribution focusses exclusively on samples of forearc mantle serpentinites from the Cuaba Unit (collected along the Rio Cuevas and at Lomá Quita Espuela); it is these serpentinites which exhibit various degrees of compositional zoning of Cr-spinel.

\section{Analytical methods}

Serpentinite samples were collected along the Rio Cuevas (samples RD45, RD48 and RD60) and at Lomá Quita Espuela (samples RD34a, RD34c, RD68, RD6-36a and RD6-36c). The Cr-spinels were examined by transmitted-light and incidentlight microscopy. Backscattered-electron (BSE) images were collected using a Lamont four element solid-state detector and BSE Quad Summing Amplifier. Mineral compositions (27 grains) were determined on an automated CAMEBAX MBX electron microprobe using four wavelength-dispersive spectrometers. Counting times were $15 \mathrm{~s}$ per element, except for Fe (20 s) and $\mathrm{Ni}(40 \mathrm{~s})$. A $15 \mathrm{kV}$ accelerating potential and $20 \mathrm{nA}$ beam current were used. The calibration standards were pure wollastonite $(\mathrm{Si}$, $\mathrm{Ca})$, synthetic spinel (Al), synthetic $\mathrm{Cr}_{2} \mathrm{O}_{3}(\mathrm{Cr})$, forsterite $(\mathrm{Mg})$, synthetic $\mathrm{MnTiO}_{3}(\mathrm{Mn}, \mathrm{Ti})$, pure vanadium metal $(\mathrm{V})$, albite $(\mathrm{Na})$, fayalite $(\mathrm{Fe}$ in silicates), synthetic $\mathrm{Fe}_{2} \mathrm{O}_{3}$ ( $\mathrm{Fe}$ in oxides), tugtupite $(\mathrm{Cl})$ and synthetic lithium fluoride $(\mathrm{F})$.

The $\mathrm{Fe}_{2} \mathrm{O}_{3}$ content of the Cr-spinel was calculated assuming stoichiometric compositions (e.g. Bliss and MacLean, 1975; Dick and Bullen, 1984; Barnes and Roeder, 2001). One drawback of this method is that errors associated with other elements propagate into larger errors in estimated $\mathrm{Fe}^{3+}$ (Wood and Virgo, 1989). This is important to recognize when dealing with relatively small variations in ferric iron content (Barnes and Roeder, 2001). However, we consider this effect to be negligible in our samples (Table 1) because $\mathrm{Fe}_{2} \mathrm{O}_{3}$ values are generally high (>2 wt.\%), and intragrain variations are significant (>10 wt.\%).

Serpentine-group minerals were identified using powder X-ray diffraction and microRaman spectrometry. The analytical methods pertaining to these are described by Saumur et al. (2010).

\section{Results}

\section{Petrography of the Cuaba serpentinites}

All of the samples are almost fully hydrated (11-14\% loss on ignition) and are dominated by pseudomorphic mesh-textured serpentine after olivine (Saumur et al., 2010). Bastite after orthopyroxene is rarely observed. Samples $\mathrm{RD} 34 \mathrm{a}$ and $\mathrm{RD} 68$ are the only ones in which minor amounts $(<1$ vol.\%) of primary olivine $\left(\mathrm{Fo}_{90}\right)$ and orthopyroxene $\left(\mathrm{En}_{89-91}\right)$ remain; in most samples Cr-spinel is the only preserved primary mineral. Fine-grained dusty magnetite forms less than 1 vol. $\%$ of samples and has nearendmember compositions. Samples RD34 and RD6-36 contain minor talc and tremolite $(<2$ vol. $\%)$ and traces of cummingtonite. No secondary metamorphic olivine and pyroxene were found.

Powder X-ray diffraction (XRD), micro-Raman spectrometry and microscopy suggest that the dominant serpentine-group mineral is lizardite, with minor chrysotile (Saumur et al., 2010). The

FIG. 5 (facing page). Examples of well zoned Cr-spinels. (a) Transmitted-light photomicrograph of the Cr-spinel grain in plane-polarized light. Note the chlorite (Chl, clear, high relief) around the Cr-spinel (Cr-spl) which overprints lizardite (Liz) and is intergrown with magnetite (Mag) (Sample RD-34c). Magnetite has an endmember composition, similar to dusty magnetite disseminated in lizardite. (b) Backscattered-electron image of the Cr-spinel shown in Fig. $4 a$; Note the polygonal pervasive fractures (relicts of trellis exsolution or partings) and brighter rims due to higher $\mathrm{Fe}^{3+}$ \# than cores. (c) Backscattered-electron image of Cr-spinel showing gradual compositional zoning contrast with magnetite overgrowths. Magnetite is intergrown with chlorite (black), and the matrix is lizardite (also black) (Sample RD48). (d) Backscattered-electron image of $\mathrm{Cr}$-spinel with diffuse zoning, surrounded by overgrowths of symplectitic magnetite (bright) and chlorite (dark). Dark areas in the cores of the grain are aggregates of chlorite and lizardite. Note the minor microscopic fractures in the lower portion of the grain (Sample RD48). (e) Backscattered-electron image of a Cr-spinel grain showing gradual zoning, partly surrounded by intergrowths of magnetite and chlorite. Composition variation along the transect ('Chr-transect') is shown in Fig. 6. Note the minor microscopic fractures at the bottom right corner of the grain. (f) Incident light photomicrograph of the grain shown in Fig. $4 e$ under open polars. Note the similar intragrain reflectivity of $\mathrm{Cr}$-spinel in contrast to the high reflectivity of magnetite surrounding the grain, which suggest that they are two distinct phases. 
ZONED CR-SPINEL AND FERRITCHROMITE ALTERATION
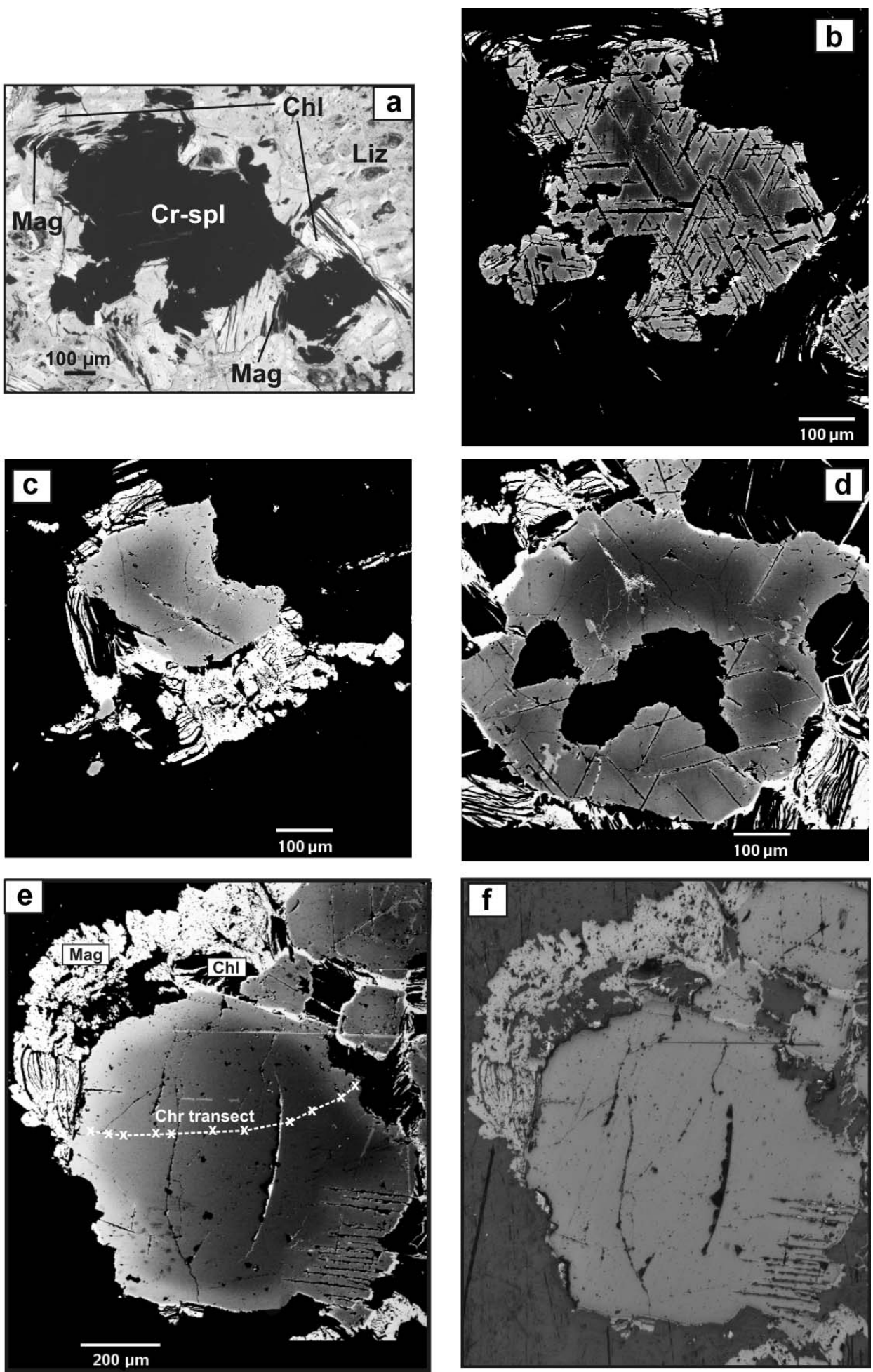


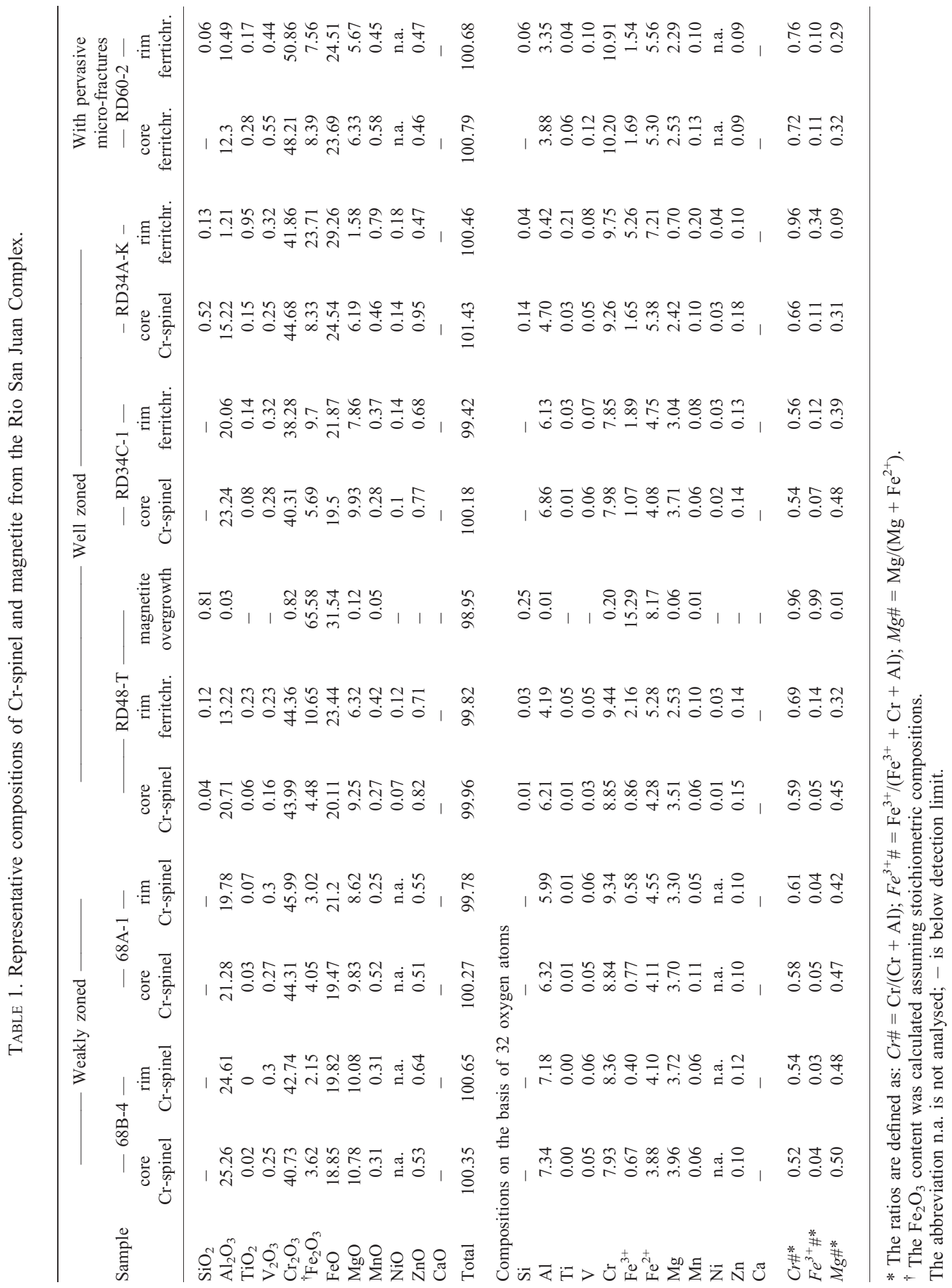


pseudomorphic mesh texture of lizardite suggests that olivine was converted to lizardite, which is typical of low-temperature serpentinization (O'Hanley, 1996). The high-temperature serpentine-group mineral antigorite (e.g. Evans, 2004), was not detected by XRD or micro-Raman spectrometry. Thus, the mineralogy and textural relationships suggest that the Cuaba serpentinites have undergone a relatively low degree of heating. Lizardite grains analysed in this study have variable total $\mathrm{Fe}(2.65-11.22$ wt.\%) and $\mathrm{Al}$ (0.03-1.18 wt. $\left.\% \mathrm{Al}_{2} \mathrm{O}_{3}\right)$ contents.

\section{Chromium-spinel}

Chromium-spinel constitutes less than 1 vol.\% of the serpentinites. Grain sizes vary within samples, some are as small as $50 \mu \mathrm{m}$, but most are between 0.3 and $1.2 \mathrm{~mm}$. Grains are subhedral-to-anhedral, and rarely are vermicular or embayed. They appear dark red to dark brown (Fig. $4 a$ ) or opaque in transmitted light (Fig. 5a). Their opacity appears to be broadly correlated with their $\mathrm{Fe}^{3+}$ content.

The compositions of the cores of Cr-spinel grains are similar within individual samples. They are characterized by moderate $\mathrm{Cr} \#$ [i.e. atomic $\mathrm{Cr} /(\mathrm{Cr}+\mathrm{Al})]$ ratios of $0.48-0.66$ and moderate $\mathrm{Mg} \#$ [i.e. atomic $\mathrm{Mg} /\left(\mathrm{Mg}+\mathrm{Fe}^{2+}\right)$ ] ratios of $0.40-0.51$ (Table 1; Fig. 3a). Most grains, with some exceptions, have low $\mathrm{Fe}^{3+} \#$ [i.e. atomic $\left.\mathrm{Fe}^{3+} /\left(\mathrm{Cr}+\mathrm{Al}+\mathrm{Fe}^{3+}\right)\right]$ ratios of $0.03-0.10$, which are within the range expected for mantle-wedge peridotites (e.g. Ishii et al., 1992; Ohara and Ishii, 1998; Fig. 3b). These features, along with low Ti $\left(<0.21\right.$ wt. $\left.\% \mathrm{TiO}_{2}\right)$ contents, suggest that the grain cores are not significantly metamorphosed, and probably represent primary compositions. The $\mathrm{Zn}$ content in the $\mathrm{Cr}$-spinel cores varies from 0.46 to 0.95 wt. $\% \mathrm{ZnO}$, which is unusually high for $\mathrm{Cr}-$ spinels in mantle-wedge peridotites (see compilation by Arai and Ishimaru, 2011).

On the basis of the observed textural and compositional changes in the Cr-spinel, a sequence of events can be established. Chromium-spinel grains from sample RD68 are weakly zoned (and are termed 'weakly zoned' in Fig. 3 and subsequent figures). The edges of these grains are slightly brighter in backscatteredelectron (BSE) images (Fig. $4 b-d$ ) as a result of an increase in their $\mathrm{Fe}^{2+}$ content and a decrease in $\mathrm{Mg}^{2+}$. However, zoning is patchy and a concentric pattern is not well developed (Fig. $4 c$, top left side of grain; Fig $4 d$, top part of grain). The $\mathrm{Cr} \#$ ratios are slightly higher at the grain rims, as shown by the slightly darker zones in close proximity to the bright rims in the BSE images (Fig. $4 c-d$ ), and in diffuse darker areas within the grains (Fig. $4 b$ ). The $\mathrm{Fe}^{3+}$ content at the rims remains low and is similar to that at the cores (Table 1).

The Cr-spinel in all of the other samples described in this study (RD34a, RD34c, RD636, RD45, RD48 and RD60) exhibits more prominent compositional zoning (termed 'well zoned' in Fig. 3 and subsequent figures) than sample RD68. In transmitted light, such grains are either nearly opaque or have dark brown cores which gradually increase in opacity toward their rims (Fig. 5a). Gradational concentric compositional zoning is apparent in BSE images (Fig. $5 c-e$ ). In addition to a decrease in $M g \#$ and a small increase in $\mathrm{Cr}$ content, a pronounced increase in $\mathrm{Fe}^{3+} \#$ occurs at the rims (Figs 3 and 6a). Rim compositions plot close to the low Fe end of the ferritchromite composition field (Figs $3 b$ and 7) which is defined by published data on ferritchromite in ultramafic rocks metamorphosed under amphibolite facies conditions reported from other localities (e.g. Evans and Frost, 1975; Pinsent and Hirst, 1977; Liipo et al., 1995b; Suita and Strieder, 1996; Barnes and Roeder, 2001). Overall, the rims of well zoned grains have lower $\mathrm{Al}, \mathrm{Mg}$, and $\mathrm{Zn}$ contents and are enriched in $\mathrm{Fe}, \mathrm{Cr}, \mathrm{Ti}, \mathrm{Mn}, \mathrm{Ni}$ and $\mathrm{V}$ compared to the cores (Table 1; Figs 6-8).

Several grains of Cr-spinel in samples RD60 and RD34a (Fig. $5 a, b$ ) are cut by numerous microscopic fractures which intersect at constant angles within a given grain. These fractures are commonly filled with clinochlore or lizardite. Although such fractures might represent the octahedral spinel partings described by Deer et al. (1992), it is also possible that they represent relics of lattice exsolution along $\{111\}$ crystallographic planes. Such exsolution has been reported to occur in $\mathrm{Cr}$-spinel during oxidation (Haggerty, 1991). These grains have similar compositions to the well zoned grains described above ('with pervasive fractures' in Fig. 3 and in subsequent figures), but have partly or completely lost the zoning pattern observed in the well zoned grains (Figs 3 and $5 b$ ). The $\mathrm{Fe}^{3+}$ and $\mathrm{Fe}^{2+}$ contents adjacent to fractures (Fig. 5c) and possible exsolution relics (Fig. 5b,d,e) are commonly elevated, and show up as bright areas in BSE images, extending up to $50 \mu \mathrm{m}$ away from the fractures. Furthermore, the compositions of grains with pervasive microscopic fractures plot just 
B. M. SAUMUR AND K. HATTORI
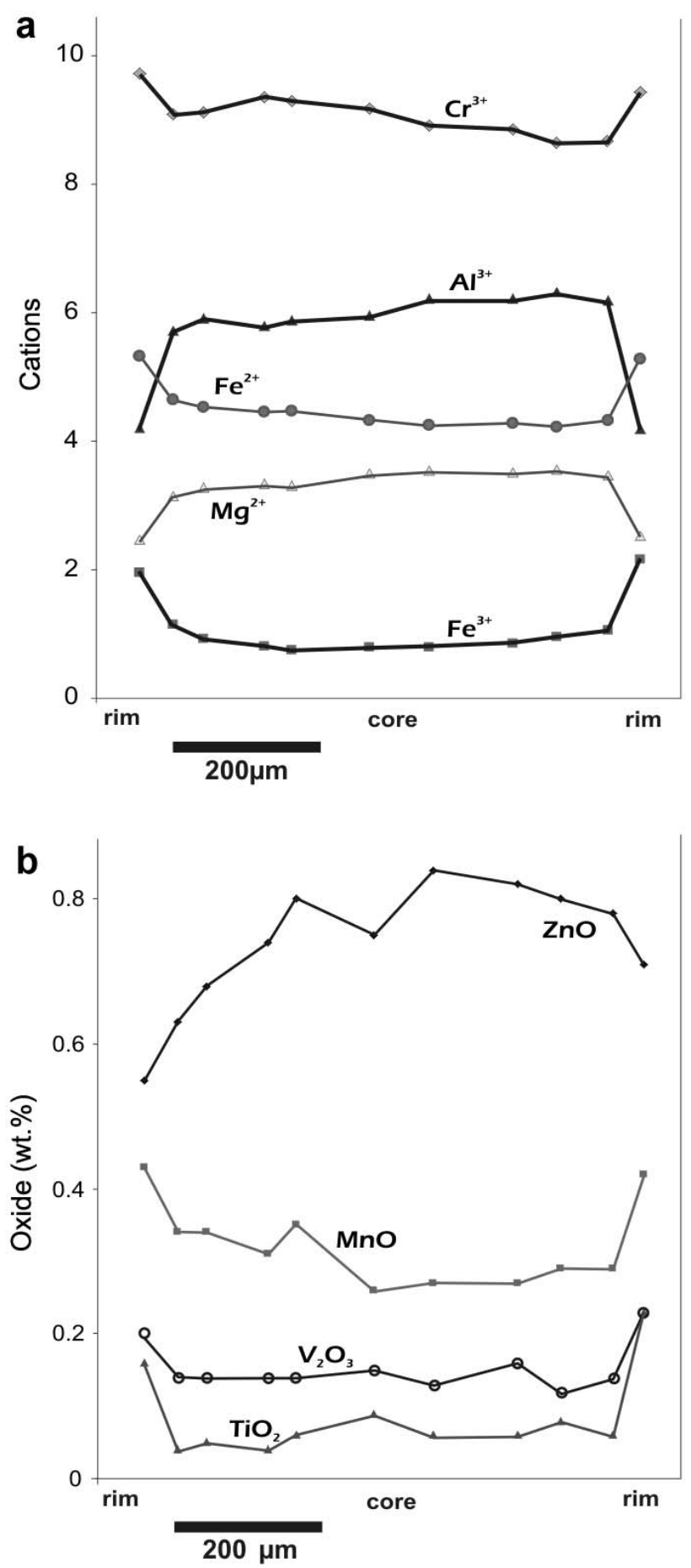

FIG. 6. Compositional variation along the transect of the zoned Cr-spinel grain shown in Fig. $4 e, f$ (from sample $\mathrm{RD}$ 48). The $\mathrm{Fe}^{3+}$ contents are calculated assuming stoichiometric composition of $\mathrm{Cr}$-spinel. (a) Major elements and (b) minor elements. 


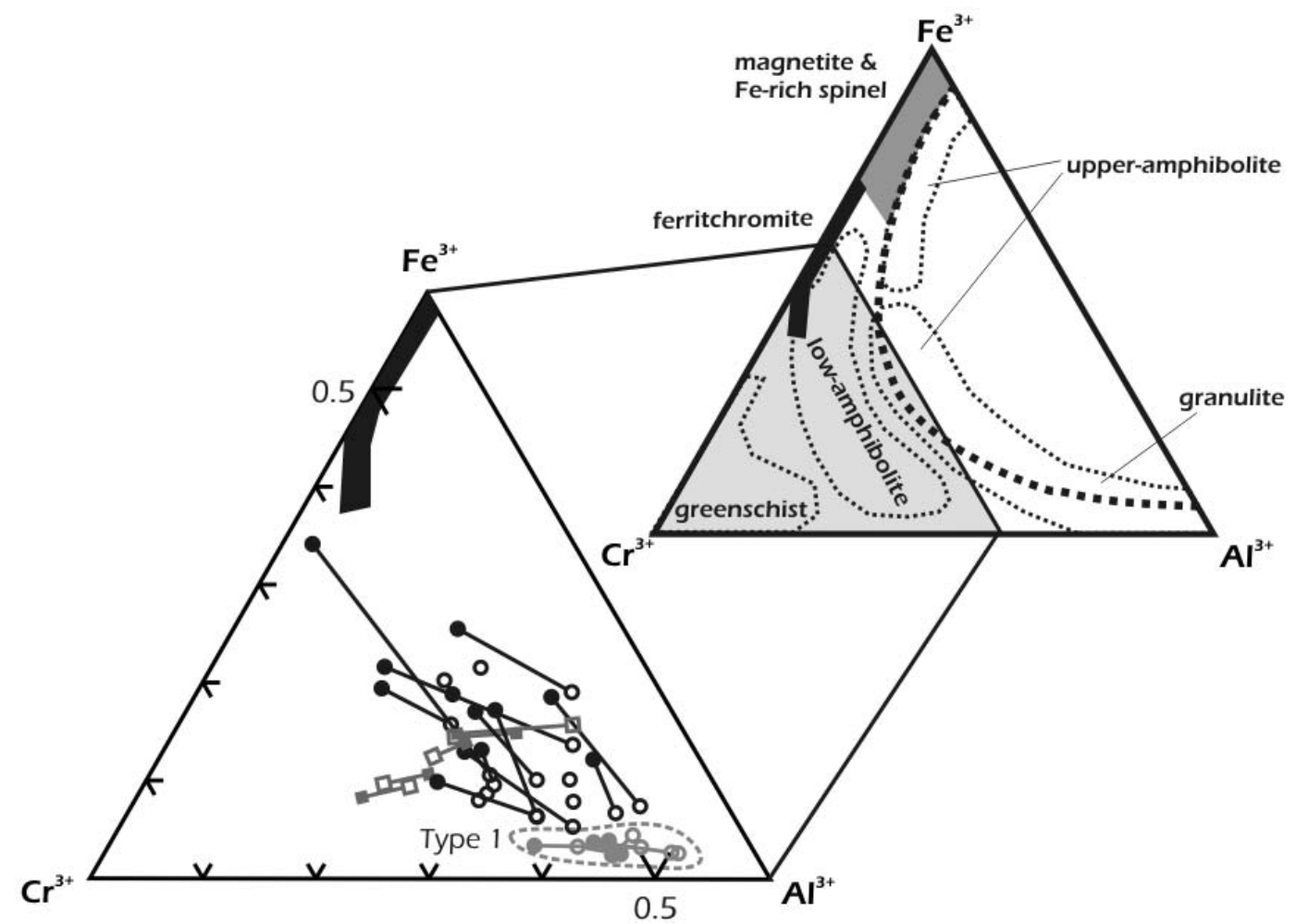

Fig. 7. Ternary diagram of atomic $\mathrm{Cr}^{3+}-\mathrm{Fe}^{3+}-\mathrm{Al}^{3+}$ compositions. As in Fig. 3, the magnetite in the Cuaba samples is low in $\mathrm{Cr}$ and plots in the field of 'mag rims'. The field for ferritchromite and its compositional trend was obtained from data and diagrams given by Barnes and Roeder (2001), Pinsent and Hirst (1977) and Liipo et al. (1995b). Fields for greenschist, lower-amphibolite, upper-amphibolite and granulite-grade spinels were obtained from Evans and Frost (1975) and Suita and Strieder (1996), as cited by González-Jiménez et al. (2009).

outside the fields of forearc peridotite (Fig. 3), and show relatively high $\mathrm{Fe}^{3+} \#(0.11-0.22)$ and high Ti (0.15-1.07 wt.\% $\mathrm{TiO}_{2}$, mostly below 0.40 wt.\%). These observations suggest that fluid penetration along intragrain fractures caused localized alteration and even homogenization of Cr-spinel. Nevertheless, these compositions remain close to primary and, as discussed more fully in the following text, are markedly different from typical ferritchromite or metamorphosed Cr-spinel.

\section{Clinochlore and magnetite}

Well zoned Cr-spinel is commonly partially surrounded by coronae of Mg-rich chlorite, hereafter described as clinochlore $(M g \#=0.94-0.96$; Table 2), which contains significant $\mathrm{Cr}_{2} \mathrm{O}_{3}$ (1.24-3.01 wt.\%). The clinochlore is subhedral and bladed in shape, overprints mesh-textured lizardite (Fig. $5 a$ ), and is commonly intergrown with magnetite near Cr-spinel grains (Fig. $5 c, d$ ) suggesting contemporaneous crystallization.

Magnetite commonly occurs at or near rims of all types of Cr-spinel and, like the dusty magnetite grains within the serpentine matrix, has nearendmember compositions $\left(F e^{3+} \#=0.97\right.$; $M g \#=0)$. The evidence supports its formation during serpentinization, as suggested by Evans and Frost (1975). Such magnetite around zoned Cr-spinel grains forms a distinct phase from the Fe-enriched rims of zoned Cr-spinel (Fig. 5f).

\section{Discussion}

Origin of zoning: alteration sequence of $\mathrm{Cr}$ spinel

Textural evidence suggests that the zoning observed in Cr-spinel is not a primary feature; but instead appears to be due to alteration. Indeed, there appears to be a relationship between zoning 


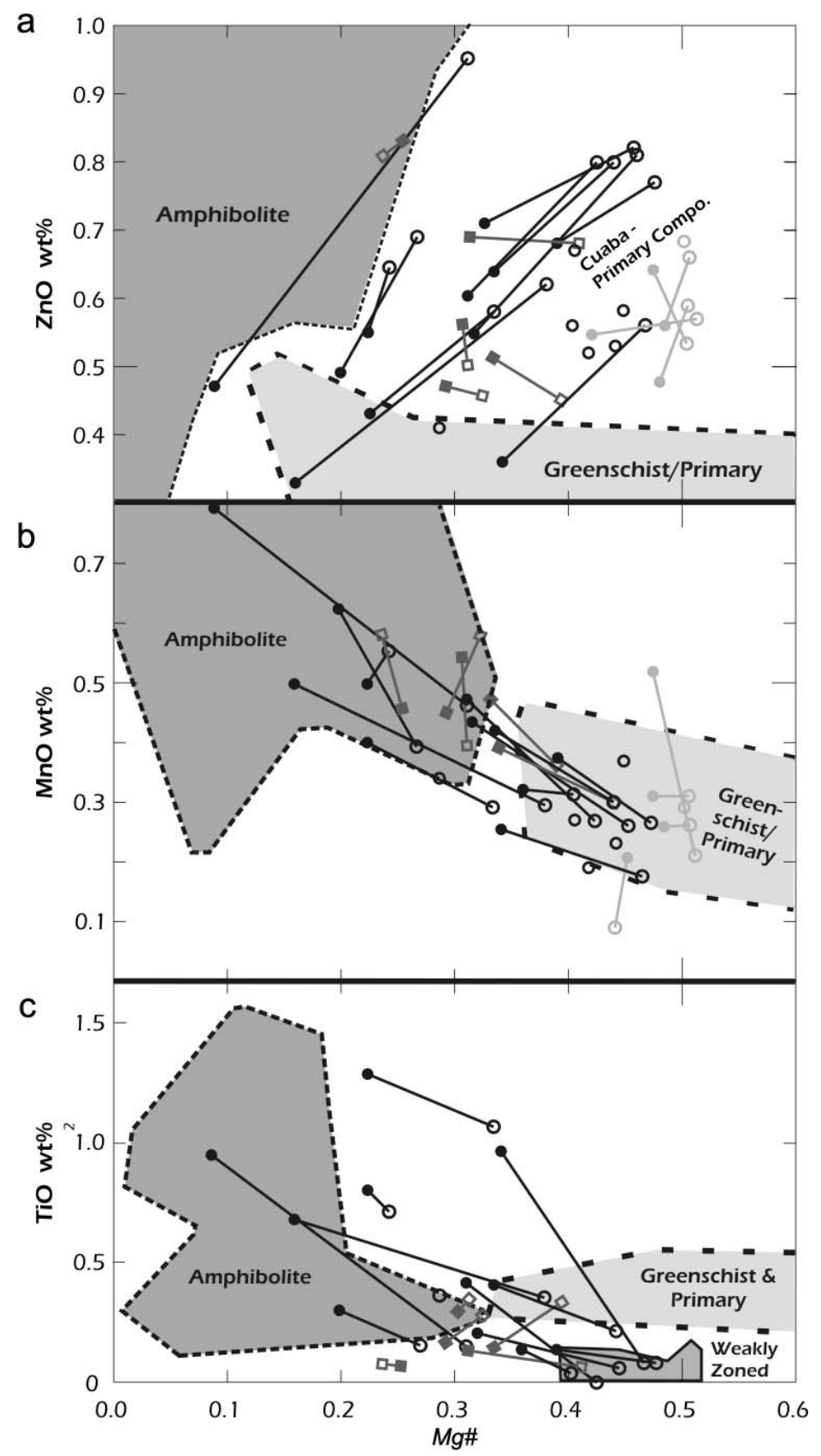

FIG. 8. Minor-element contents $v s . M g \#$ in Cr-spinel. Symbols are as in Fig. 3, with open symbols representing cores (primary compositions), and filled symbols representing rims. (a) $\mathrm{ZnO} v s . M g \# ; ~(b) \mathrm{MnO} v s . M g \# ;(c) \mathrm{TiO}_{2} v s . M g \#$. The composition field for Cr-spinel in amphibolite-facies metamorphic rocks is based on data compiled by Barnes (2000) for Cr-spinel in metamorphosed komatiites (see text for discussion). Only those parts of the compositional space relevant to the Cuaba samples are shown. Chromium-spinel which has been metamorphosed under amphibolite-facies conditions commonly contains high $\mathrm{Zn}$ (up to $\sim 8.0 \mathrm{wt} . \% \mathrm{ZnO}$ ) and $\mathrm{Mn}$ (up to $\sim 2.7 \mathrm{wt} . \% \mathrm{MnO}$ ) which are beyond the values shown in these diagrams. 


\section{ZONED CR-SPINEL AND FERRITCHROMITE ALTERATION}

TABLE 2. Representative clinochlore (Mg-dominant chlorite) compositions from the Rio San Juan Complex.

\begin{tabular}{|c|c|c|c|c|c|}
\hline & 636B-C-7 & 636B-B-4 & $636 \mathrm{C}-1-1$ & 48-tra-19 & $34 \mathrm{~A}-\mathrm{K}-5$ \\
\hline $\mathrm{SiO}_{2}$ & 32.48 & 31.24 & 32.13 & 32.42 & 31.56 \\
\hline $\mathrm{Al}_{2} \mathrm{O}_{3}$ & 16.59 & 17.1 & 15.98 & 13.93 & 17.55 \\
\hline $\mathrm{TiO}_{2}$ & 0.11 & 0.1 & - & - & - \\
\hline $\mathrm{Cr}_{2} \mathrm{O}_{3}$ & 1.24 & 1.82 & 2.04 & 3.01 & 1.79 \\
\hline $\mathrm{FeO}$ & 3.06 & 3.52 & 3.84 & 2.79 & 3.65 \\
\hline $\mathrm{MgO}$ & 32.6 & 32.52 & 33.71 & 33.59 & 33.4 \\
\hline $\mathrm{CaO}$ & - & 0.01 & 0.01 & - & 0.01 \\
\hline $\mathrm{Cl}$ & 0.03 & 0.02 & n.a. & 0.04 & n.a. \\
\hline $\mathrm{F}$ & 0.22 & 0.17 & 0.14 & 0.04 & n.a. \\
\hline Total & 86.33 & 86.5 & 87.85 & 85.83 & 87.97 \\
\hline \multicolumn{6}{|c|}{ Formula on the basis of 28 oxygen atoms } \\
\hline $\mathrm{Si}$ & 6.18 & 5.97 & 6.06 & 6.24 & 5.93 \\
\hline $\mathrm{Al}$ & 1.82 & 2.03 & 1.94 & 1.76 & 2.07 \\
\hline Sum & 8.00 & 8.00 & 8.00 & 8.00 & 8.00 \\
\hline $\mathrm{Al}$ & 1.91 & 1.83 & 1.62 & 1.40 & 1.81 \\
\hline $\mathrm{Ti}$ & 0.02 & 0.01 & - & - & - \\
\hline $\mathrm{Cr}$ & 0.19 & 0.28 & 0.31 & 0.46 & 0.27 \\
\hline $\mathrm{Fe}$ & 0.49 & 0.56 & 0.61 & 0.45 & 0.57 \\
\hline $\mathrm{Mg}$ & 9.25 & 9.27 & 9.48 & 9.64 & 9.35 \\
\hline $\mathrm{Ca}$ & - & 0.00 & 0.00 & - & 0.00 \\
\hline Sum & 11.85 & 11.95 & 12.01 & 11.95 & 12.00 \\
\hline $\mathrm{Cl}$ & 0.01 & 0.01 & n.a. & 0.02 & n.a. \\
\hline $\mathrm{F}$ & 0.13 & 0.10 & 0.08 & 0.01 & n.a. \\
\hline Sum & 0.14 & 0.11 & 0.08 & 0.04 & n.a. \\
\hline$M g \# *$ & 0.95 & 0.94 & 0.94 & 0.96 & 0.94 \\
\hline
\end{tabular}

* The ratio $M g \#=\mathrm{Mg} /(\mathrm{Mg}+\mathrm{Fe})$.

The abbreviation n.a. is not analysed; - is below detection limit.

and the degree of hydration and metamorphism of the serpentinite as shown by the following observations: (1) weakly zoned Cr-spinel occurs in sample RD68 which contains primary silicate minerals; (2) apart from sample RD34a, well zoned Cr-spinel occurs in samples which are fully hydrated; (3) grains with abundant fractures occur in samples which show evidence of higher-grade metamorphism, such as the rare cummingtonite, talc and tremolite. Furthermore, the occurrence of clinochlore coronae around $\mathrm{Cr}$-spinel and the texture of clinochlore overprinting lizardite confirm that the zoning in Cr-spinel and the crystallization of clinochlore post-dated serpentinization.

In cumulate rocks, zoning in Cr-spinel might originate as a result of reactions with the intercumulus liquid. However, this mechanism is not applicable to the samples described herein as the serpentinites have a bulk rock geochemistry inconsistent with a cumulate origin, and consistent with an origin as hydrated residual mantle peridotite (Fig. 2; Saumur et al., 2010). There is a possibility that residual mantle peridotites could have reacted with partial melts in the mantle wedge; however, such peridotites would have low $\mathrm{Mg}$ contents in the silicate minerals and bulk rocks (e.g. Kelemen et al., 1990; Morgan and Liang, 2003). Therefore, this possibility can be discounted on the basis of the high $M g \#$ of relict olivine, relict orthopyroxene and bulk rocks. In addition, there is no textural evidence to support this possibility.

We propose the following zoning sequence. The first stage involves the replacement of $\mathrm{Mg}^{2+}$ 
by $\mathrm{Fe}^{2+}$ with constant $\mathrm{Fe}^{3+}$, as observed in 'weakly zoned' Cr-spinel, with possible minor replacement of $\mathrm{Al}^{3+}$ by $\mathrm{Cr}^{3+}$. The second stage is illustrated by the formation of well zoned $\mathrm{Cr}$-spinel. The formation, which involves an increase in $\mathrm{Fe}^{3+} \mathrm{\#}$ at grain rims or along intragrain fractures and the replacement of $\mathrm{Al}^{3+}$ by $\mathrm{Fe}^{3+}$. The $\mathrm{Al}^{3+}$ lost from the Cr-spinel during the alteration process allows the formation of clinochlore coronae around the $\mathrm{Cr}$-spinel grains. The crystallization of ferritchromite and clinochlore is facilitated by reactions between $\mathrm{Cr}$ spinel and serpentine or $\mathrm{Mg}$ - and Si-rich fluids (e.g. Mellini et al., 2005; Merlini et al., 2009). Iyer et al. (2008) suggest the following reactions:

$\mathrm{Cr}$-spinel $+\mathrm{Fe}^{3+}+\mathrm{H}_{2} \mathrm{O} \rightarrow$

Ferritchromite + Magnetite $+\mathrm{Al}^{3+}+\mathrm{H}_{2}$

$\mathrm{Al}^{3+}+$ Serpentine $+\mathrm{H}_{2} \mathrm{O} \rightarrow$ Clinochlore

By combining these reactions, reaction (3) is obtained, which is consistent with intergrowths of magnetite and clinochlore around Cr-spinel grains, and clinochlore overprinting lizardite:

Cr-spinel $+\mathrm{Fe}^{3+}+2 \mathrm{H}_{2} \mathrm{O}+$ Serpentine $\rightarrow$

Ferritchromite + Magnetite + Clinochlore $+\mathrm{H}_{2}(3)$

The reactions outlined above do not explain the increases in $\mathrm{Cr}$ observed in the rims in both weakly (Fig. $4 b-d$ ) and well zoned (e.g. Fig. 6a) Cr-spinel grains. Kimball (1990) showed that during Cr-spinel breakdown, $\mathrm{Cr}$ is preferentially incorporated in $\mathrm{Cr}$-spinel and $\mathrm{Al}$ in clinochlore, and that this results in higher $\mathrm{Cr}$ and lower $\mathrm{Al}$ in the remaining $\mathrm{Cr}$-spinel. Although this explanation is consistent with the compositions of the zoned Cr-spinel which have clinochlore coronae, it does not explain the slight increase in $\mathrm{Cr} \#$ in the rims of weakly zoned $\mathrm{Cr}$-spinel grains which lack marginal clinochlore. The small increase in $\mathrm{Cr}^{3+}$ could be partly primary (before serpentinization); for example, it could be related to partial melting which would have preferentially removed $\mathrm{Al}$ and consequently increased the $\mathrm{Cr}$ content of $\mathrm{Cr}$-spinel in the residue. Alternatively, a reaction involving $\mathrm{Cr}^{3+}$ and $\mathrm{Al}^{3+}$ exchange between $\mathrm{Cr}$-spinel and lizardite may have increased the $\mathrm{Cr}$ content of the $\mathrm{Cr}$-spinel. Lizardite is known to incorporate $\mathrm{Al}$ into its structure near to its upper thermal stability limit at $\sim 300^{\circ} \mathrm{C}$ (Caruso and Chernosky, 1979; Evans, 2004). If Al was sequestered by the surrounding lizardite, this would reduce the $\mathrm{Al}$ and increase the $\mathrm{Cr}$ content in the outer part of the Cr-spinel.
The alteration sequence in these samples is similar to that reported from the Kalkan Chromitite in the southern Urals by Merlini et al. (2009). The serpentine-group mineral in the Kalkan Chromitite is antigorite, which contrasts with the dominance of lizardite in this study. Therefore the polymorphism of the serpentine phase involved in the reaction with $\mathrm{Cr}$-spinel appears to have no bearing on the occurrence of ferritchromite alteration.

\section{Thermal conditions of alteration of Cr-spinel}

The formation of ferritchromite in serpentinites requires heating after serpentinization (e.g. Cerny, 1968), and a variety of conditions have been proposed for its onset. Temperatures between $300^{\circ} \mathrm{C}$ and $400^{\circ} \mathrm{C}$ during greenschist-facies metamorphism (Standish et al., 2002; Iyer et al., 2008; González-Jiminez et al., 2009; Merlini et al., 2009), and as high as $500^{\circ} \mathrm{C}$ during amphibolite-grade metamorphism (e.g. Bliss and MacLean, 1975; Pinsent and Hirst, 1977; Barnes, 2000; Mellini et al., 2005), have been proposed. Furthermore, different types of reactions have been proposed for the formation of ferritchromite. Divalent cations in Cr-spinel are known to be mobile at low temperatures (Barnes, 2000) and alteration in $\mathrm{Cr}$-spinel similar to that reported here in the weakly zoned samples has been observed in greenschist-facies metamorphic rocks (e.g. Evans and Frost, 1975; Suita and Strieder, 1996; González-Jiménez et al., 2009). The mobility of trivalent cations, notably $\mathrm{Fe}^{3+}$, is favoured by oxidizing conditions, which typically occur in serpentinites during prograde metamorphism after serpentinization (Frost, 1985).

The compositions of the Cr-spinel rims in our study differ from ferritchromite compositions reported from amphibolite grade metamorphic terranes. Indeed, the $\mathrm{Fe}^{3+} \#$ ratios of $0.03-0.35$ at grain rims are low compared to those of typical ferritchromite (usually $>0.5$, see Fig. 7 ), and the $\mathrm{Zn}, \mathrm{Mn}$ and Ti contents are generally lower than ferritchromite in amphibolite-grade rocks (Fig. 8, see discussion below). Such compositions suggest that ferritchromite is not fully developed and is compositionally immature. Furthermore, ferritchromite in amphibolite-grade rocks commonly replaces the entire $\mathrm{Cr}$-spinel grains, whereas in these samples the alteration is, for the most part, limited to the outer rims. Finally, in high metamorphic grade terranes, complete clinochlore coronae are common around Cr-spinel grains, whereas only partial clinochlore coronae have 
developed in our samples. Thus, compositional and textural evidence suggest that reaction 3 is incomplete, and that the rims of zoned Cr-spinel represent only the initial stages of ferritchromite alteration.

The immature development of ferritchromite is further supported by the rarity of high-temperature minerals in the Cuaba serpentinites. Cummingtonite, tremolite and talc occur only rarely in samples RD34 and RD6-36. Cummingtonite is generally considered to form at high temperatures (e.g. Frost, 1975; Evans, 1977), whereas talc and tremolite, although they form over a wide range of temperatures, generally crystallize above $400^{\circ} \mathrm{C}$ (Evans and Frost, 1975). Samples containing these minerals also contain Cr-spinel showing extensive microscopic fractures representing the highest degree of $\mathrm{Cr}$-spinel alteration observed in this study. High-temperature phases are notably absent in sample RD68, which shows only subtle zoning in the Cr-spinel. The correlation of the high-temperature minerals and the alteration of Cr-spinel suggests that they are formed by related processes.

Although some high-temperature minerals were identified, the Cuaba serpentinites are dominated by lizardite, which is stable at temperatures of up to $\sim 300^{\circ} \mathrm{C}$ (Evans, 2004; Schwartz et al., 2013). Lizardite alters to antigorite at higher temperatures, but no antigorite was detected in the samples. Furthermore, no textural evidence for the retrograde replacement of antigorite by lizardite was observed. Lizardite typically exhibits mesh, hourglass and bastitic pseudomorphic textures after primary olivine and orthopyroxene. The occurrence of lizardite with rare hightemperature phases suggests that it was, at some point, metastable. It is probable that the thermal event, with a peak temperature which appears to have been in excess of $300^{\circ} \mathrm{C}$, was too short-lived to allow the conversion of lizardite to antigorite.

Therefore, the degree of alteration of Cr-spinel and the overall mineralogy of the Cuaba serpentinites are consistent with heating above the serpentinization temperature, which is consistent with previous work. However, we emphasize that in the case of the Cuaba serpentinites, this thermal event was probably brief, inhibiting the conversion of lizardite to antigorite, resulting in the rarity of high-temperature minerals, and preventing the complete development of ferritchromite and clinochlore coronae.

The major element compositional variations in Cr-spinel documented in this study are similar to those reported from chromitites in the Dobromirtsi Massif in southeast Bulgaria (González-Jiménez et al., 2009). Those samples show an analogous sequence of alteration, defined by initial increases in $\mathrm{Cr}^{3+}$ and $\mathrm{Fe}^{2+}$ and associated decreases in $\mathrm{Al}^{3+}$ and $\mathrm{Mg}^{2+}$, followed by an increase in $\mathrm{Fe}^{3+}$ at grain rims. The first stages of alteration occur at greenschist-facies conditions, and subsequent increases in $\mathrm{Fe}^{3+}$ occur at higher grade metamorphic conditions. Although the sequence of alteration is consistent with that described in this study, the compositional changes are greater in extent in Dobromirtsi samples than in Cuaba samples because of sustained high-grade metamorphism under amphibolite facies conditions.

\section{Primary Zn content of Cr-spinel}

The $\mathrm{Zn}$ contents in Cr-spinel cores from the Cuaba serpentinites range between 0.46 and 0.95 wt.\% $\mathrm{ZnO}$ (Fig. 8a). Previous work has suggested that $\mathrm{Zn}$ concentrations in excess of $0.5 \mathrm{wt} . \% \mathrm{ZnO}$ in Cr-spinel are noteworthy (Groves et al., 1983; Wylie et al., 1987; Johan and Ohnenstetter, 2010, and references therein). They are especially uncommon in forearc mantle peridotites, probably because of the mildly incompatible behaviour of $\mathrm{Zn}$ during partial melting of the mantle which is inferred from the slightly higher $\mathrm{Zn}$ contents of mid-oceanic ridge basalt and continental crust compared to the primitive mantle value (e.g. McDonough and Sun, 1995).

A high $\mathrm{Zn}$ content in $\mathrm{Cr}$-spinel, of $1-8$ wt.\% $\mathrm{ZnO}$, is common in metamorphosed ultramafic rocks, (e.g. Paktunc and Cabri, 1995; Barnes, 2000; Säntti et al., 2006). However, the general lack of a metamorphic overprint on the $\mathrm{Cr}$-spinel cores in the Cuaba samples suggests that a metamorphic origin for the high $\mathrm{Zn}$ contents is unlikely. Interactions with late-stage magmatic fluids, which are known to cause metasomatic Zn-enrichment in Cr-spinel (e.g. Johan and Ohnenstetter, 2010), is also unlikely as the Cuaba serpentinites originated from residual mantle peridotite.

High $\mathrm{Zn}$ contents in $\mathrm{Cr}$-spinels in forearc peridotites might be explained by their reequilibration with olivine prior to serpentinization. Zinc has a strong affinity with spinel compared to other silicate minerals. The partition coefficient of $\mathrm{Zn}$ between $\mathrm{Cr}$-spinel and olivine is far greater than 10 and strongly dependent on temperature, with higher $\mathrm{Zn}$ contents in $\mathrm{Cr}$-spinel expected at lower 


\section{B. M. SAUMUR AND K. HATTORI}

temperatures (e.g. Ryan et al., 1996; De Hoog et al., 2010). The subduction zone below the Caribbean plate was exceptionally cool: a lawsonite schist was produced in the RSJC and Samaná Peninsula (Zack et al., 2004; Schertl et al., 2012); and the geothermal gradient of the subduction zone is estimated to have been $\sim 8^{\circ} \mathrm{C} \mathrm{km}^{-1}$ (Zack et al., 2004; Krebs et al., 2008; Schertl et al., 2012). Thus the high $\mathrm{Zn}$ contents of the Cr-spinel cores could be attributed to the unusually cool temperatures of the northern Caribbean forearc.

\section{Behaviour of minor elements during Cr-spinel alteration}

The compositions of Cr-spinel in the Cuaba samples can be compared to those of spinel in komatiites compiled by Barnes (2000). Using the diagrams presented in that contribution, we have created fields for 'amphibolite' and 'greenschist/ primary' spinel (Fig. 8). The komatiites are variably metamorphosed and the plots illustrate the compositional characteristics of Cr-spinel which has undergone metamorphism. Spinel in amphibolite-facies rocks has consistently high $\mathrm{Zn}$, $\mathrm{Mn}$ and Ti contents and lower $\mathrm{Mg \#}$ compared to that in greenschist-facies rocks (Fig. 8).

In the Cuaba samples, the $\mathrm{Cr}$-spinel rims have lower concentrations of $\mathrm{Zn}(0.32-0.71$ wt.\% $\mathrm{ZnO}$; Fig. $8 a$ ) compared to cores, and their compositions plot in the field for $\mathrm{Cr}$-spinel that has been metamorphosed under greenschist-facies conditions. Compositional variations between cores and rims suggest that $\mathrm{Zn}$ behaves like $\mathrm{Mg}$ (Fig. 6) and is liberated from Cr-spinel during initial-stage reactions with serpentine or $\mathrm{Mg}$ - and Si-rich fluids, as suggested by González-Jiménez et al. (2009). If these samples had undergone amphibolite-facies metamorphism and the duration of this event had been sufficient to alter the compositions of $\mathrm{Cr}$-spinel, an enrichment in $\mathrm{Zn}$ would be expected in Cr-spinel, comparable to that observed amphibolite-grade spinels in komatiites (Fig. 8).

The Mn contents of the Cr-spinel cores are low (0.15-0.47 wt.\% MnO; Fig. $8 b$ ), and the rims show a progressive increase in Mn with increasing total $\mathrm{Fe}$ content, with some plotting in, or near, the amphibolite field. The behaviour of $\mathrm{Ti}$ is similar to that of Mn (Figs $6 b$ and $8 c$ ). Increasing $\mathrm{Mn}$ and $\mathrm{Ti}$ are most probably the result of alteration of Cr-spinel, consistent with the well documented increases of $\mathrm{Mn}$ and $\mathrm{Ti}$ in Cr-spinel in amphibolite-grade rocks (Barnes, 2000). The evidence suggests that $\mathrm{Mn}$ and Ti follow the same well documented progressive enrichment during alteration as Cr-spinels reported in metamorphosed komatiites (Fig. 8b,c). Furthermore, our data suggests that they may be enriched in Cr-spinel prior to $\mathrm{Zn}$ during prograde metamorphism, although this might depend on the composition of the syn-metamorphic fluid.

Vanadium has a wide range of oxidation states, from +2 to +5 . Divalent and trivalent $\mathrm{V}$ are compatible with silicate and oxide minerals, but pentavalent $\mathrm{V}$ is incompatible (Mallmann and O’Neill, 2009). As mantle wedges are generally oxidized (e.g. Parkinson and Arculus, 1999; Wang et al., 2008), $\mathrm{V}$ in forearc and subarc mantle is expected to be incompatible. Consequently, V contents are low in the mantle and in Cr-spinel (Richter et al., 2006). During metamorphism, the $\mathrm{V}$ content of Cr-spinel generally increases, as shown by the high (9 wt. \% as $\mathrm{V}_{2} \mathrm{O}_{3}$ ) content in some rocks metamorphosed to amphibolite-facies conditions (Säntti et al., 2006). Although V levels are not as high in the Cuaba samples, the slight increase in $\mathrm{V}$ at grain rims (Fig. 6b) is consistent with previous reports (Säntti et al., 2006) of V enrichment during $\mathrm{Cr}$-spinel alteration.

\section{Causes of Cr-spinel zoning in forearc serpentinites}

As noted in the introduction, ferritchromite is very rare in forearc mantle peridotites. Our detailed examination of forearc mantle serpentinites in the Marianas and the Himalayas failed to identify ferritchromite (Saumur et al., 2011). Furthermore, ferritchromite is notably absent in forearc serpentinite along the Camú fault which originated from the same forearc mantle as the Cuaba samples, but is closer to the trench than these samples from the Septentrional fault, (Fig. 1; Saumur et al., 2010).

The lack of ferritchromite alteration in typical forearc mantle serpentinites can be explained by thermal histories which differ from that of the Cuaba serpentinites. Forearc mantle serpentinites are usually exhumed from the base of a mantle wedge in subduction channels located along subducting plates (e.g. Gerya et al., 2006), and such exhumation is accompanied by a simple cooling, without heating which would cause these serpentinites to go through amphibolite-facies conditions. The occurrence of ferritchromite alteration in the Cuaba samples suggests that 
they have been affected by a late heating event atypical of usual serpentinite exhumation. The reports of amphibolite-facies conditions within Omi forearc serpentinites, which also exhibit ferritchromite in accessory Cr-spinel (Tsujimori et al., 2004) are consistent with this suggestion.

There are two possible explanations for the occurrence of ferritchromite in the Cuaba samples. The first possibility is related to the protrusion of these serpentinites from the base of the mantle wedge towards higher crustal levels along the Septentrional fault zone (Saumur et al., 2010). The interiors of mantle wedges are hotter than their bases near the slab, and therefore Cuaba serpentinites would have been heated during their protrusion through the forearc. This would also explain the lack of ferritchromite in serpentinites along the Camú fault zone: because of their position closer to the palaeo-trench, compared to Cuaba serpentinites, the Camú serpentinites would have protruded through a thinner and cooler mantle wedge than the Cuaba serpentinites, and therefore would not have experienced significant temperature increases during protrusion.

The second possible source of heating is related to the emplacement of the Rio Boba Intrusion, which is located $1-2 \mathrm{~km}$ north of Rio Cuevas and Loma Quita Espuela (Fig. 1). Again, this explanation would be consistent with the lack of $\mathrm{Cr}$-spinel zoning in CFZ serpentinites, which are located at a greater distance from the known northern extent of the Rio Boba Intrusion ( $>15 \mathrm{~km})$, and thus were probably unaffected by its emplacement.

\section{Conclusion}

We report the rare occurrence of ferritchromite alteration of $\mathrm{Cr}$-spinel in forearc serpentinites located in the southern part of the RSJC in the northern Dominican Republic. Ferritchromite occurs rarely in hydrated forearc mantle peridotites because they are not commonly heated during exhumation.

Chromium-spinels in this study record the early stages of ferritchromite formation. The first stage of alteration is characterized by the replacement of $\mathrm{Mg}^{2+}$ by $\mathrm{Fe}^{2+}$ and, to a lesser extent, $\mathrm{Al}^{3+}$ by $\mathrm{Cr}^{3+}$. This is followed by the replacement of $\mathrm{Al}^{3+}$ by $\mathrm{Fe}^{3+}$ at slightly higher temperatures. The $\mathrm{Mg}$ and $\mathrm{Al}$ (and minor $\mathrm{Cr}$ ) released from $\mathrm{Cr}$-spinel produce partial coronae of $\mathrm{Cr}$-bearing clinochlore, which is commonly intergrown with magnetite. This alteration occurred at conditions at which lizardite, the dominant species of serpentinite in these rocks, was metastable, and rare highertemperature minerals such as talc, tremolite and cummingtonite crystallized. Thus, the observed Cr-spinel zoning (i.e. compositionally and texturally immature ferritchromite rims) is interpreted to have formed in response to a short-lived thermal event that did not allow the full development of ferritchromite and clinochlore coronae.

The contents of $\mathrm{Ti}$ and $\mathrm{Mn}$ in the $\mathrm{Cr}$-spinel rims are consistent with our interpretation that the serpentinites underwent only minor degrees of metamorphism. Relatively high $\mathrm{Zn}$ in the cores reflect cool temperatures of the northern Caribbean mantle wedge, whereas lower $\mathrm{Zn}$ at rims was produced during the early stages of $\mathrm{Cr}$ spinel alteration.

This study confirms that the compositions of Cr-spinel may be modified during low-grade metamorphism. Some caution must therefore be exercised in using Cr-spinel compositions for petrogenetic studies, even in slightly metamorphosed serpentinites.

\section{Acknowledgements}

Funding from an NSERC Postgraduate Scholarship, an Ontario Graduate Scholarship, and a Québec Graduate Scholarship during his MSc studies at the University of Ottawa is acknowledged by BMS. This work was funded in part by an NSERC Discovery Grant to KHH. Stéphane Guillot is thanked for fruitful discussions and his insights. Peter Jones (Carleton University) assisted with microprobe analyses and George Mrazek (University of Ottawa) with preparation of thin sections. Constructive comments by Chris Hayward, Brian O'Driscoll and an anonymous reviewer improved the clarity of this manuscript. Principal Editor Roger Mitchell is thanked for editing an early version of this manuscript. Alexander Cruden is thanked by BMS for providing him with the opportunity to complete this manuscript during the course of his $\mathrm{PhD}$ studies.

\section{References}

Abbott, R.N. Jr and Draper, G. (2010) Comment on "Corundum-bearing garnet peridotites from northern Dominican Republic: a metamorphic product of an arc cumulate in the Caribbean subduction zone," by Hattori et al. [Lithos 114 (2010) 437-450]. Lithos, 
$117,322-326$.

Arai, S. and Ishimaru, S. (2011) Zincian chromite inclusions in diamonds: possibility of deep recycling origin. Journal of Mineralogical and Petrological Sciences, 106, 85-90.

Barnes, S.J. (2000) Chromite in komatiites; II. Modification during greenschist to mid-amphibolite facies metamorphism. Journal of Petrology, 41, 387-409.

Barnes, S.J. and Roeder, P.L. (2001) The range of spinel compositions in terrestrial mafic and ultramafic rocks. Journal of Petrology, 42, 2279-2302.

Beeson, M.H. and Jackson, E.D. (1969) Chemical composition of altered chromites from the Stillwater complex, Montana. American Mineralogist, 74, 1084-1100.

Bliss, N.W. and Maclean, W.H. (1975) The paragenesis of zoned chromite from central Manitoba. Geochimica et Cosmochimica Acta, 39, 973-990.

Caruso, L.J. and Chernosky, J.V. Jr (1979) The stability of lizardite. The Canadian Mineralogist, 17, 757-769.

Cerny, P. (1968) Comments on serpentinization and related metasomatism. American Mineralogist, 53, $1377-1385$.

De Hoog J.C.M., Gall, L. and Cornell, D.H. (2010) Trace-element geochemistry of mantle olivine and application to mantle petrogenesis and geothermobarometry Chemical Geology, 270, 196-215.

De Hoog, J.C.M. (2012) Comments on "Garnet-bearing ultramafic rocks from the Dominican Republic: fossil mantle plume fragments in an ultra high pressure oceanic complex?" by Gazel et al. [Lithos, 125, 393-404] Lithos, 134/135, 330-334.

Deer, W.A., Howie, R.A. and Zussman, J. (1992) An Introduction to the Rock-Forming Minerals, second edition. Pearson Prentice Hall, Harlow, UK, 696 pp.

Dick, H.J.B. and Bullen, T. (1984) Chromian spinel as a petrogenetic indicator in abyssal and alpine-type peridotites and spatially associated lavas. Contributions to Mineralogy and Petrology, 86, $54-76$.

Draper, G. and Nagle, F. (1991) Geology, structure, and tectonic development of the Rio San Juan Complex, northern Dominican Republic. Special Paper Geological Society of America, 262, 77-95.

Evans, B.W. (1977) Metamorphism of alpine peridotite and serpentinite. Annual Review of Earth and Planetary Sciences, 5, 397-447.

Evans, B.W. (2004) The serpentinite multisystem revisited; chrysotile is metastable. International Geology Review, 46, 479-506.

Evans, B.W. and Frost, B.R. (1975) Chrome-spinel in progressive metamorphism; a preliminary analysis. Geochimica et Cosmochimica Acta, 39, 959-972.

Frost, B.R. (1975) Contact metamorphism of serpenti- nite, Chloritic backwall, and rodingite at Paddy-GoEasy Pass, Central Cascades, Washington. Journal of Petrology, 16, 272-313.

Frost, B.R. (1985) On the stability of sulfides, oxides and native metals in serpentinite. Journal of Petrology, 26, 31-63.

Gazel, E., Abbott, R.N. Jr and Draper, G. (2011) Garnetbearing ultramafic rocks from the Dominican Republic: fossil mantle plume fragments in an ultra high pressure oceanic complex? Lithos, 125, 393-404.

Gazel, E., Abbott, R.N. Jr and Draper, G. (2012) Reply to comment on "Garnet-bearing ultramafic rocks from the Dominican Republic: fossil mantle plume fragments in an ultra high pressure oceanic complex?" by Jan C.M. De Hoog. Lithos, 134-135, 335-339.

Gerya, T.V., Connolly, J.A.D., Yuen, D.A., Gorczyk, W. and Capel, A.M. (2006) Seismic implications of mantle wedge plumes. Physics of Earth Planetary Interiors, 156, 59-74.

Groves, D.I., Barrett, F.M., Brotherton, R.H., de Villiers, J.P.R. and Cawthorn, P.A. (1983) Exploration significance of chrome-spinels in mineralized ultramafic rocks and nickel-copper ores. Special Publication - Geological Society South Africa, 7, $21-30$.

González-Jiménez, J.M., Kerestedjian, T., Proenza, J.A. and Gervilla, F. (2009) Metamorphism on chromite ores from the Dobromirtsi Ultramafic Massif, Rhodope Mountains (SE Bulgaria). Geologica Acta, 7, 413-429.

Gorczyk, W., Guillot S., Gerya, T.V. and Hattori, K.H. (2007) Asthenospheric upwelling, oceanic slab retreat and exhumation of UHP mantle rocks: insights from Greater Antilles. Geophysical Research Letters, 34, http://dx.doi.org/10.1029/ 2007GL031059.

Guillot, S., Hattori, K.H., de Sigoyer, J., Naegler, T. and Auzende, A.L. (2001) Evidence of hydration of the mantle wedge and its role in the exhumation of eclogites. Earth and Planetary Science Letters, 193, 115-127.

Haggerty, S.E. (1991) Oxide textures - a mini-altas. Pp. 129-137 in: Oxide Minerals: Petrological and Magnetic Significance (D.H. Lindsley, editor) Reviews in Mineralogy, 25. The Mineralogical Society of America, Washington DC.

Hattori, K.H. and Guillot, S. (2007) Geochemical character of serpentinites associated with high- to ultrahigh-pressure metamorphic rocks in the Alps, Cuba, and the Himalayas: recycling of elements in subduction zones. Geochemistry Geophysics Geosystems, 8, http://dx.doi.org/10.1029/ $2007 \mathrm{GC} 001594$.

Hattori, K.H., Guillot, S., Saumur, B.M., Tubrett, M.N., 
Vidal, O. and Morfin, S. (2010a) Corundum-bearing garnet peridotite from northern Dominican Republic: a metamorphic product of an arc cumulate in the Caribbean subduction zone. Lithos, 114, 437-450.

Hattori, K.H., Guillot, S., Tubrett, M.N., Saumur, B.-M., Vidal, O. and Morfin, S. (2010b) Reply to comment on "Corundum-bearing garnet peridotites from northern Dominican Republic: a metamorphic product of an arc cumulate in the Caribbean subduction zone" by Richard N. Abbott and Grenville Draper. Lithos, 117, 327-330.

Irvine, T.N. (1967) Chromian spinel as a petrogenetic indicator; Part 2. Petrologic applications. Canadian Journal of Earth Sciences, 4, 71-103.

Ishii, T., Robinson, P.T., Maekawa, H. and Fiske, L. (1992) Petrological studies of peridotites from diapiric serpentinite seamounts in the IzuOgasawara-Mariana forearc, Leg 125. Proceedings of the Ocean Drilling Program Scientific Results, 125, 445-485.

Iyer, K., Austrheim, H., John, T. and Jamtveit, B. (2008) Serpentinization of the oceanic lithosphere and some geochemical consequences: constraints from the Leka ophiolite complex, Norway. Chemical Geology, 249, 66-90.

Johan, Z. and Ohnenstetter, D. (2010) Zincochromite from the Guaniamo River diamondiferous placers, Venezuela: evidence of its metasomatic origin. The Canadian Mineralogist, 48, 361-374.

Kelemen, P.B., Joyce, D.B., Webster, J.D. and Holloway, J.R. (1990) Reaction between ultramafic rock and fractionating basaltic magma II. Experimental investigation of reaction between olivine tholeiite and harzburgite at $1150-1050^{\circ} \mathrm{C}$ and $5 \mathrm{~kb}$. Journal of Petrology, 31, 99-134.

Kimball, K.L. (1990) Effects of hydrothermal alteration on the compositions of chromian spinels. Contributions to Mineralogy and Petrology, 105, 337-346.

Krebs, M., Maresch, W.V., Schertl, H.P., Münker, C., Baumann, A, Draper, G., Idleman, B. and Trapp, E. (2008) The dynamics of intra-oceanic subduction zones: a direct comparison between fossil petrological evidence (Rio San Juan Complex, Dominican Republic) and numerical simulation. Lithos, 103, 106-137.

Lewis, J.F., Draper, G., Bourdon, C., Bowin, C., Mattson, P.O., Maurrasse, F., Nagle, F. and Pardo, G. (1990) Geology and tectonic evolution of the northern Caribbean margin. Pp. 77-150 in: The Caribbean Region (G. Dengo and J.E. Case, editors). The Geology of North America, volume $\mathbf{H}$. Geological Society of America, Boulder, Colorado, USA.

Liipo, J.P., Vuollo, J.I., Nykanen, V.M. and Piirainen, T.A. (1995a) Zoned Zn-rich chromite from the
Naataniemi serpentinite massif, Kuhmo greenstone belt, Finland. The Canadian Mineralogist, 33, 537-545.

Liipo, J., Vuollo, J., Nykanen, V., Piirainen, T., Pekkarinen, L. and Tuokko, I. (1995b) Chromites from the early Proterozoic Outokumpu-Jormua ophiolite belt; a comparison with chromites from Mesozoic ophiolites. Lithos, 36, 15-27.

Mann, P. and Gordon, M.B. (1996) Tectonic uplift and exhumation of blueschist belts along transpressional strike-slip fault zones. Geophysical Monograph, 96, $143-154$.

Mallmann, G. and O'Neill (2009) The crystal/melt partitioning of $\mathrm{V}$ during mantle melting as a function of oxygen fugacity compared with some other elements (Al, P, Ca, Sc, Ti, Cr, Fe, Ga, Y, Zr, and $\mathrm{Nb})$. Journal of Petrology, 50, 1765-1794.

Morgan, Z. and Liang, Y. (2003) An experimental numerical study of the kinetics of harzburgite reactive dissolution with application to dunite dike formation. Earth and Planetary Science Letters, 214, 59-74.

Mcdonough, W.F. and Sun, S.S. (1995) The composition of the Earth. Chemical Geology, 120, 223-253.

Mellini, M., Rumori, C. and Viti, C. (2005) Hydrothermally reset magmatic spinels in retrograde serpentinites: formation of "ferritchromit" rims and chlorite aureoles. Contributions to Mineralogy and Petrology, 149, 266-275.

Merlini, A., Greico, G. and Diella, V. (2009) Ferritchromite and chromian-chlorite in mélange hosted Kalkan chromitite (Southern Urals, Russia). American Mineralogist, 94, 1459-1467.

Niu, Y. (2004) Bulk-rock major and trace element compositions of abyssal peridotites: implications for mantle melting, melt extraction and post-melting processes beneath mid-ocean ridges. Journal of Petrology, 45, 2423-2458.

O'Hanley, D.S. (1996) Serpentinites: Recorders of Tectonic and Petrological History. Oxford Monographs on Geology and Geophysics, 34. Oxford University Press, New York.

Ohara, Y. and Ishii, T. (1998) Peridotites from the southern Mariana forearc: heterogeneous fluid supply in the mantle wedge. Island Arc, 7, 541-558.

Onyeagocha, A.C. (1974) Alteration of chromite from the Twin Sisters Dunite, Washington. American Mineralogist, 59, 608-612.

Paktunca, A.D. and Cabrib, L.J. (1995) proton- and electron-microprobe study of gallium, nickel and zinc distribution in chromian spinel. Lithos, 35, 261-282.

Parkinson, I.J. and Pearce, J.A. (1998) Peridotites from the Izu-Bonin-Mariana forearc (ODP Leg 125): evidence for mantle melting and melt-mantle interaction in a supra-subduction zone setting. 


\section{B. M. SAUMUR AND K. HATTORI}

Journal of Petrology, 39, 1577-1618.

Parkinson, I.J. and Arculus, R.J. (1999) The redox state of subduction zones: insights from arc-peridotites. Chemical Geology, 160, 409-423.

Peacock, S.M. (1996) Thermal and petrologic structure of subduction zones. Geophysical Monographs (Subduction Top to Bottom), 96, 119-133.

Pindell, J. and Draper, G. (1991) Geologic development of the Puerto Plata region, northern Dominican Republic. Pp. 97-114 in: Geological and tectonic development of the North American-Caribbean plate boundary in Hispaniola (P. Mann, G. Draper and J.F. Lewis, editors). Geological Society of America, Special Paper 262. Geological Society of America, Boulder, Colorado, USA.

Pindell, J., Maresch, W.V., Martens, U. and Stanek, K. (2012) The Greater Antillean Arc: Early Cretaceous origin and proposed relationship to Central American subduction mélanges: implications for models of Caribbean evolution. International Geology Review, 54, 131-143.

Pinsent, R.H. and Hirst, D.M. (1977) The metamorphism of the Blue River ultramafic body, Cassiar, British Columbia, Canada. Journal of Petrology, 18, 567-594.

Richter, K., Sutton, S.R., Newville, M., Le, L., Schwandt, C.S., Uchida, H., Lavina, B. and Downs, R.T. (2006) An experimental study of the oxidation state of vanadium in spinel and basaltic melt with implications for the origin of planetary basalt. American Mineralogist, 91, 1643-1656.

Ryan, C.G., Griffin, W.L. and Pearson, N.J. (1996) Garnet geotherms: pressure-temperature data from Cr-pyrope garnet xenocrysts in volcanic rocks. Journal of Geophysical Research, 101, 5611-5625.

Säntti, J., Kontinen, A., Sorjonen-Ward, P., Johanson, B. and Pakkanen, L. (2006) Metamorphism and chromite in serpentinized and carbonate-silicaaltered peridotites of the Paleoproterozoic Outokumpu-Jormua ophiolite belt, Eastern Finland. International Geology Review, 48, 494-546.

Saumur, B.M., Hattori, K.H. and Guillot, S. (2010) Contrasting origins of serpentinites in a subduction complex, northern Dominican Republic. Geological Society of America Bulletin, 122, 292-304.

Saumur, B.M., Hattori, K.H., Stern F. and Jackson S. (2011) Major and trace element compositions of Crspinel from serpentinized forearc mantle peridotites: insights on geochemical processes during melt extraction and metamorphism. Geological Society of America Abstracts with Programs, 43, 588.
Schertl, H.P., Maresch, W.V., Stanek, KP, Hertwig, A., Krebs, M., Baese, R. and Sergeev, S.S. (2012) New occurrences of jadeitite, jadeite quartzite and jadeitelawsonite quartzite in the Dominican Republic, Hispaniola: petrological and geochronological overview. European Journal of Mineralogy, 24, 199-216.

Schwartz, S., Guillot, S., Reynard, B., Lafay, R., Debret, B., Nicollet, C., Lanari, P. and Auzende, A.L. (2013) Pressure-temperature estimates of the lizardite/ antigorite transition in high pressure serpentinites. Lithos, http://dx.doi.org/10.1016/j.1ithos. 2012.11.023

Spangenberg, K. (1943) Die chromitlaagerstatte von tampedal in Zobten. Zeitschrift für Praktische Geologie, 51, 13-35.

Standish, J.J., Hart, S.R., Blusztajn, J., Dick, H.J.B. and Lee, K.L. (2002) Abyssal peridotite osmium isotopic compositions from Cr-spinel. Geochemistry Geophysics Geosystems, 3, 1-24.

Suita, M.T. and Strieder, J.A. (1996) Cr-spinels from Brazilian mafic-ultramafic complexes: metamorphic modifications. International Geology Review, 38, 245-267.

Tsujimori, T., Kojima, S., Takeuchi, M. and Tsukada, K. (2004) Origin of serpentinites in the Omi serpentinite melange (Hida Mountains, Japan) deduced from zoned Cr-spinel. Journal of the Geological Society of Japan, 110, 591-597.

Ulmer, G.C. (1974) Alteration of Chromite During Serpentinization in the Pennsylvania-Maryland District. American Mineralogist, 59, 1236-1241.

Wang, J., Hattori, K.H., Li, J.P. and Stern, C. (2008) Oxidation state of Paleozoic subcontinental lithospheric mantle below the Pali Aike. Lithos, 105, 98-110.

Wood, B.J. and Virgo, D. (1989) Upper mantle oxidation state: ferric iron contents of lherzolite spinels by ${ }^{57} \mathrm{Fe}$ Mossbauer spectroscopy and resultant oxygen fugacities. Geochimica and Cosmochimica Acta, 53, 1277-1291.

Wylie, A.G., Candela, P.A. and Burke, T.M. (1987) Compositional zoning in unusual $\mathrm{Zn}$-rich chromite from the Sykesville District of Maryland and its bearing on the origin of "ferritchromit". American Mineralogist, 72, 413-422.

Zack, T., Rivers, T., Brumm, R. and Kronz, A. (2004) Cold subduction of oceanic crust: Implications from a lawsonite eclogite from the Dominican Republic. European Journal of Mineralogy, 16, 909-916. 